\title{
Correction to: Equal Airtime: Body Maps and Narrative Stories by Sex Workers in South Africa
}

\author{
Elsa Alexandra Oliveira ${ }^{1}$
}

Published online: 28 May 2018

(C) Society for International Development 2018

\section{Correction to: Development https://doi.org/10.1057/s41301-018-0146-9}

Owing to a misunderstanding, the author's name and affiliation were deleted during the preparation of the article for publication.
The author of this article is:

E. A. Oliveira

Post-Doctoral Fellow, African Centre for Migration \& Society (ACMS), University of the Witwatersrand, South Africa

The Editor apologises for this mistake.

The original article can be found online at https://doi.org/10.1057/s41301-018-0146-9.

$\square$ Elsa Alexandra Oliveira

Elsa.alexandra.oliveira@gmail.com

1 African Centre for Migration and Society (ACMS),

University of the Witwatersrand, Johannesburg 2050,

South Africa 